\title{
Role of Calcium Ion and Cyclic Nucleotides in Pheromone Production in Bombyx mori
}

\author{
Adrien Fónagy, Shogo Matsumoto, Kyoichi Uchiumi and Takashi Mitsui \\ Insect Toxicology and Physiology Laboratory, RIKEN (The Institute of Physical and Chemical Research), \\ Hirosawa, Wako 351-01, Japan
}

(Received October 3, 1991; Accepted January 13, 1992)

\begin{abstract}
Injection of cAMP, cGMP and dbcAMP (50, 250 and $500 \mu \mathrm{g}$ ) into decapitated Bombyx mori females induced pheromone production in a dose-dependent manner. Among these cyclic nucleotides, cAMP proved to be the most active. Under in vitro conditions, however, cyclic nucleotides did not stimulate pheromone production even in a wide range of concentrations $(1 \mu \mathrm{M}-10 \mathrm{mM})$. Likewise, MIX or forskolin, or both $(10 \mu \mathrm{M}-1 \mathrm{mM})$ also failed to stimulate pheromone glands to produce bombykol, whereas, MIX $(50 \mu \mathrm{M})$ enhanced the action of Bom-PBAN-I and increased bombykol production by $30-60 \%$. In addition, both MIX $(100 \mu \mathrm{M})$ and forskolin $(100 \mu \mathrm{M})$ enhanced the action of calcium ionophore in bombykol production by two to three times. The action of PBAN on in vitro pheromone production was inhibited in a dose-dependent manner by adding lanthanium ion $(100 \mu \mathrm{M}-10 \mathrm{~mm})$ into the medium. Present results provide some evidences for the requirement of calcium ion influx, suggesting the involvement of calcium ion or CAMP, or both in the mode of action of PBAN in the pheromone glands of $B$. mori.
\end{abstract}

\section{INTRODUCTION}

Sex pheromone production in a number of moth species is controlled by pheromone biosynthesis activating neuropeptide (PBAN), which is secreted by the suboesophageal ganglion. ${ }^{1-5)}$ The primary structures of PBAN have been reported in two lepidopteran species, Heliothis zea ${ }^{6-8)}$ and Bombyx mori ${ }^{9,10)}$

Recently, a growing number of investigations have been focused on the identification of the target organ of PBAN for a clearer understanding of the mode of action of this hormone. In Heliothis armigera, Bombyx mori and Spodoptera litura, the target organ of PBAN has been demonstrated to be the pheromone gland itself. ${ }^{11-14)}$ Another model has shown that Heliothis PBAN stimulates the terminal abdominal ganglion to secrete a neurochemical factor which is responsible for pheromone production in the pheromone gland $^{15)}$ or direct, neural stimulation induced by PBAN exists via axonal branches innervating the pheromone glands ${ }^{16)}$ in $H$. zea, $H$. virescens and $H$. subflexa. In addition, reports say that the corpus bursea is the target organ of PBAN in Argyrotaenia velutinana and that it produces the "bursa factor" responsible for pheromone production. ${ }^{17)}$ These findings suggest diverse physiological mechanisms of PBAN action depending on the lepidopteran species.

To date, only a few studies have been conducted on the second messenger system in PBAN action. In $H$. armigera, it has been demonstrated that under in vitro conditions, PBAN increased the intracellular level of cAMP in the pheromone gland, resulting in pheromone production. ${ }^{11,18)}$ It has also been revealed for this species that the addition of 8-bromo-cAMP to the incubation media stimulated acetate incorporation into the pheromone. ${ }^{11)}$ This effect was further increased by adding forskolin, a stimulant of 
adenylate cyclase ${ }^{19)}$ and MIX, a potent phosphodiesterase inhibitor, ${ }^{20)}$ into the medium. On the other hand, according to our recent observations on $B$. mori, calcium ionophore mimicked the action of PBAN in vitro. ${ }^{14)}$ Since calcium ionophore is known to stimulate the penetration of divalent cations like the calcium ion, ${ }^{21)}$ the stimulating action of calcium ionophore suggests that the influx of calcium ion has a decisive role in the action of PBAN. ${ }^{14)}$ It has been previously demonstrated that various enzyme activities in diverse systems depend on calcium ion and calmodulin concentrations ${ }^{22}$ and that the synthesis or degradation of cyclic nucleotides in insect tissues also depends on calcium/calmodulin..$^{23,24)}$ Therefore, cyclic nucleotides could also be responsible for PBAN induced pheromone synthesis, at rate-limiting step(s), in the pheromone gland of B. mori.

The main objective of our present study is to elucidate some further aspects in the second messenger system involved in the mode of action of PBAN in $B$. mori by testing in vivo and in vitro effects of various cyclic nucleotides as well as some pharmacochemicals such as MIX, forskolin and lanthanium ion, a calcium ion antagonist, which is known to displace specifically the divalent cations from the plasmamembrane. ${ }^{25)}$ Our investigations are based on the previous findings that the target organ of PBAN in B. mori is the pheromone gland itself. ${ }^{13,14)}$

\section{MATERIALS AND METHODS}

\section{Insects}

Bombyx mori (Kinshu \& Showa) larvae were reared under a $16 \mathrm{~L}: 8 \mathrm{D}$ photoperiod at $25^{\circ} \mathrm{C}$ and fed on artificial diet, as previously described. ${ }^{14)}$ Newly emerged females were decapitated within $3 \mathrm{hr}$ after moulting and were kept for $24 \mathrm{hr}$ until use.

\section{Injection of Cyclic Nucleotides}

In in vivo cyclic nucleotide dose-dependence experiments, decapitated females of $B$. mori were injected with corresponding doses (50, 250 and $500 \mu \mathrm{g}$ ) of cAMP, cGMP or dibutyryl cAMP (dbcAMP) (sodium salts; SIGMA) dissolved in $10 \mu \mathrm{l}$ of distilled water. The pheromone glands were excised 90-100 min after injection and extracted with $100 \mu \mathrm{l} n$-hexane.
A $10 \mu \mathrm{l}$ aliquot of the extracts was subjected to pheromone analysis. The amount of bombykol $\{(10 E, 12 Z)-10,12$-hexadecadien-1-ol $\}$ was measured by HPLC as previously reported. ${ }^{14)}$

\section{Incubation of Pheromone Glands with Cyclic Nucleotides}

Pheromone glands taken from decapitated females of B. mori were damped-dried, cleaned of other tissue remnants and the inside of the glands were carefully washed several times with the respective incubating medium using a microsyringe. The glands were incubated at room temperature, in $150 \mu \mathrm{l}$ Grace's medium containing various concentrations of cyclic nucleotides $(1 \mu \mathrm{M}-10 \mathrm{~mm})$ for $90-100 \mathrm{~min}$. After incubation, each gland was taken out from the medium, extracted with $100 \mu \mathrm{l} n$ hexane and the amount of bombykol produced in the gland was measured as described above.

\section{Incubation of Pheromone Glands with $M I X$ or Forskolin in the Presence of Bom-PBAN- $I$}

Stock solutions of both MIX (3-isobutyl-1methylxanthine, Sigma) and forskolin (7-Ohemisuccinyl-7-deacetyl, Sigma) in DMSO (100 $\mathrm{mm}$ ) were prepared and diluted in Grace's medium. Dose dependence was studied at different concentrations of MIX or forskolin, or both.

The stimulating effect of either MIX or forskolin, or both was studied in the presence of $0.5 \mathrm{ng}$ or $1 \mathrm{ng}$ synthetic oxidized Bombyx PBAN-I ${ }^{26)} \quad($ Bom-PBAN-I $) / 150 \mu \mathrm{l} \quad$ Grace's medium. The glands were incubated and processed as described above.

\section{Incubation of Pheromone Glands with $M I X$ or Forskolin in the Presence of Calcium. Ionophore}

A stock solution (100 mM) of calcium ionophore A23187 (free acid, Sigma) was prepared in DMSO and added to the medium. Calcium ionophore was employed at different concentrations $(333,50$ and $10 \mu \mathrm{M})$ in combination with MIX or forskolin. After incubation the glands were processed as above. 
6. Incubation of Pheromone Glands with Lanthanium Ion in the Presence of BomPBAN-I

The inhibitory action of lanthanium ion, ( $\mathrm{LaCl}_{3}$, Nacalai) was studied using a series of different doses of PBAN $(2,5$ and $10 \mathrm{ng} / 150 \mu \mathrm{l}$ Grace's medium) along with a series of various concentrations of lanthanium ion $(100 \mu \mathrm{M}-10$ $\mathrm{mm})$. Glands were incubated and processed as previously described.

\section{RESULTS}

1. Effect of $c A M P, c G M P$ and $d b c A M P$ in Vivo and in Vitro

Injection of cAMP, cGMP or dbcAMP into decapitated female $B$. mori induced bombykol production in a dose-dependent manner (Fig. 1). Among the tested cyclic nucleotides cAMP was found to be the most active. In in vitro, however, when the pheromone glands were incubated with these cyclic nucleotides in a wide range of concentrations $(1 \mu \mathrm{M}-10 \mathrm{~mm})$, they failed to induce bombykol production (data are not shown).

\section{Effect of $M I X$ or Forskolin in the Presence of Bom-PBAN-I in Vitro}

As a preliminary experiment, pheromone

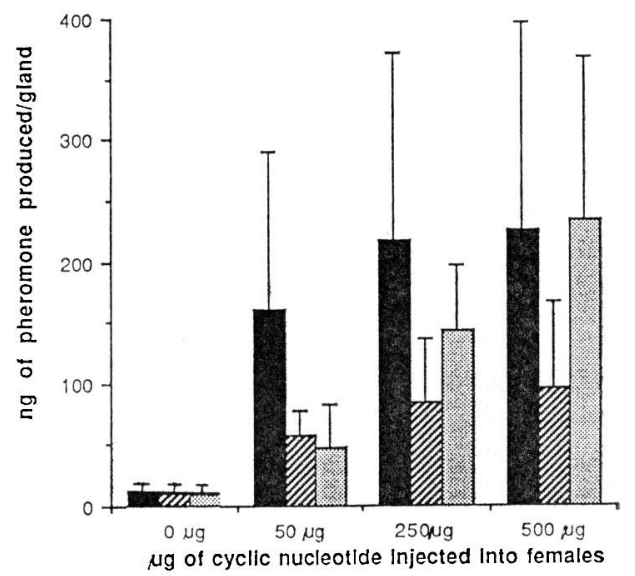

Fig. 1 In vivo effects of cyclic nucleotides on pheromone production in $B$. mori.

Solid columns represent cAMP, striped ones cGMP, and dotted ones dbcAMP treatments. Different doses of cyclic nucleotides were injected into females, while only distilled water into controls. The columns indicate a mean of minimum 9 measurements of independent gland extracts. Thin bars represent standard deviation.
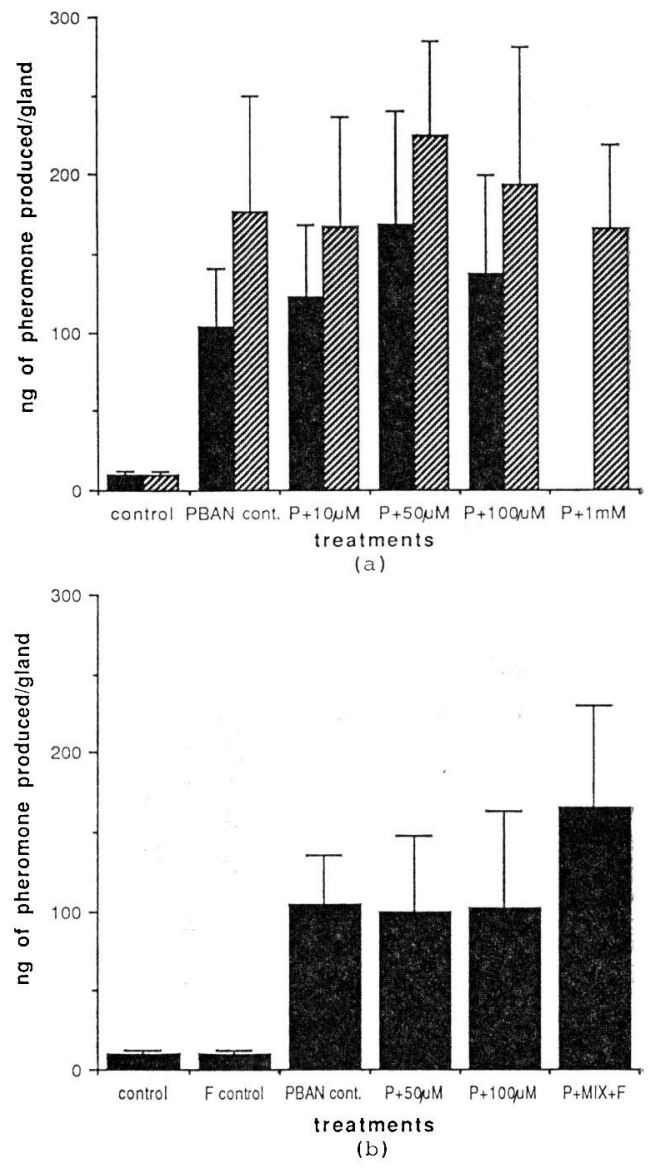

Fig. 2 In vitro effect of MIX or forskolin or both in the presence of $B o m$-PBAN-I on pheromone production in $B$. mori.

Abbreviations used on figures: F, forskolin; MIX, 3-isobutyl-1-methylxanthine and P, Bom-PBANI.

(a) Effect of MIX in the presence of 0.5 or $1 \mathrm{ng}$ Bom-PBAN-I

Control: $100 \mu \mathrm{M}$ MIX without P; PBAN cont. $0.5 \mathrm{ng} \mathrm{P} / \mathrm{vial}$ (black column); $1 \mathrm{ng} \mathrm{P} /$ vial (striped column); $\mathrm{P}+10 \mu \mathrm{M}, \mathrm{P}+50 \mu \mathrm{M}, \mathrm{P}+100 \mu \mathrm{M}$ and $\mathrm{P}+1 \mathrm{~mm}$ contain 0.5 or $1 \mathrm{ng} \mathrm{PBAN}+$ respective concentrations of MIX indicated. The columns indicate a mean of minimum 9 measurements of independent glands. Thin bars represent standard deviation. Result of $\mathrm{P}+50 \mu \mathrm{M}$ MIX significantly differ from that of PBAN cont. at $p<$ 0.05 level in Student's $t$ test.

(b) Effect of forskolin in the presence of $0.5 \mathrm{ng}$ Bom-PBAN-I

Control: glands in Grace's medium; $\mathrm{F}$ control: $100 \mu \mathrm{M}$ forskolin without P; PBAN cont. : $0.5 \mathrm{ng}$ $\mathrm{P} /$ vial; $\mathrm{P}+50 \mu \mathrm{M}$ and $\mathrm{P}+100 \mu \mathrm{m}$ contain $0.5 \mathrm{ng}$ PBAN + respective concentrations of forskolin. $\mathrm{P}+\mathrm{MIX}+\mathrm{F}$ contains $0.5 \mathrm{ng} \mathrm{PBAN}+50 \mu \mathrm{M}$ of both MIX and F. Result of $\mathrm{P}+\mathrm{MIX}+\mathrm{F}$ significantly differs from that of PBAN control at $p<0.05$ level in Student's $t$ test. Otherwise refer to Fig. 2 (a). 
glands were incubated either with MIX or forskolin $(10 \mu \mathrm{M}-1 \mathrm{~mm})$ or both, but pheromone production was not induced (Fig. 2(a) and (b); control and $\mathrm{F}$ control).

Incubation of the pheromone glands with $0.5 \mathrm{ng}$ PBAN $/ 150 \mu \mathrm{l}$ medium resulted in $102 \pm$ $35 \mathrm{ng}$ of bombykol production (at $10 \mathrm{ng}$ pheromone production in vitro was maximum with $430 \pm 165 \mathrm{ng} /$ gland $\left.^{14)}\right)$. The effect of PBAN on bombykol production was enhanced by addition of MIX to the incubation medium at concentrations between 10 and $100 \mu \mathrm{M}$. In this range, $50 \mu \mathrm{M}$ MIX increased bombykol production by $60 \%$ (Fig. 2(a)). An addition of $50 \mu \mathrm{m}$ MIX to the incubation medium containing 1 ng PBAN increased pheromone production by about $30 \%$ (Fig. 2 (a)). In con- trast, there was no enhancement of bombykol production when forskolin (50 or $100 \mu \mathrm{M}$ ) was added to the medium containing $0.5 \mathrm{ng}$ PBAN $/ 150 \mu \mathrm{l}$ (Fig. 2(b)). When both MIX and forskolin $(50 \mu \mathrm{M})$ were added to the medium, the result was similar to the one when only MIX was employed (Fig. 2(a) and (b)).

\section{Effect of MIX or Forskolin in the Presence of Calcium Ionophore in Vitro}

A twofold elevation was recorded when MIX (100 $\mu \mathrm{M})$ was added to media containing $50 \mu \mathrm{M}$ calcium ionophore (Fig. 3(a)).

In a previous study, calcium ionophore stimulated the pheromone gland to produce bombykol in vitro and the effect was optimal at a concentration of $333 \mu \mathrm{M} .{ }^{14)}$ In the present

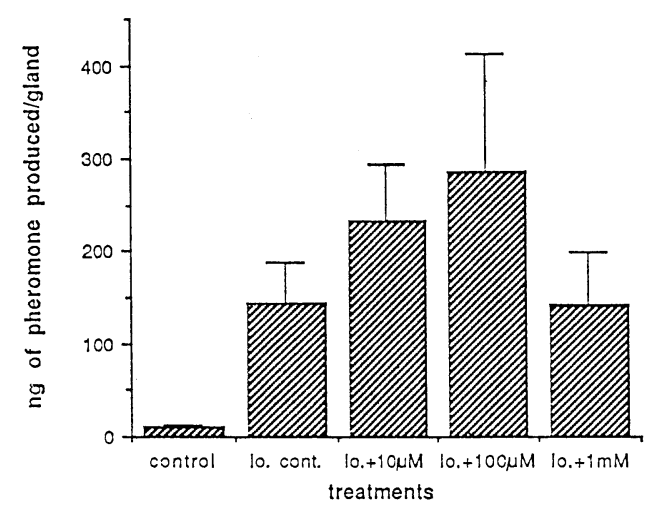

(a) Effect of MIX in the presence of $50 \mu \mathrm{M}$ calcium ionophore

Control: glands in Grace's medium; Io cont.: calcium ionophore control at $50 \mu \mathrm{M}$ concentration; Io $+10 \mu \mathrm{M}$, Io $+100 \mu \mathrm{M}$, Io $+1 \mathrm{~mm}: 50 \mu \mathrm{M}$ calcium ionophore + respective concentrations of MIX indicated. Otherwise refer to Fig. 2. Result of Io $50+100 \mu \mathrm{M}$ treatments significantly differs from that of control at $p<0.01$ level in Student's $t$ test.

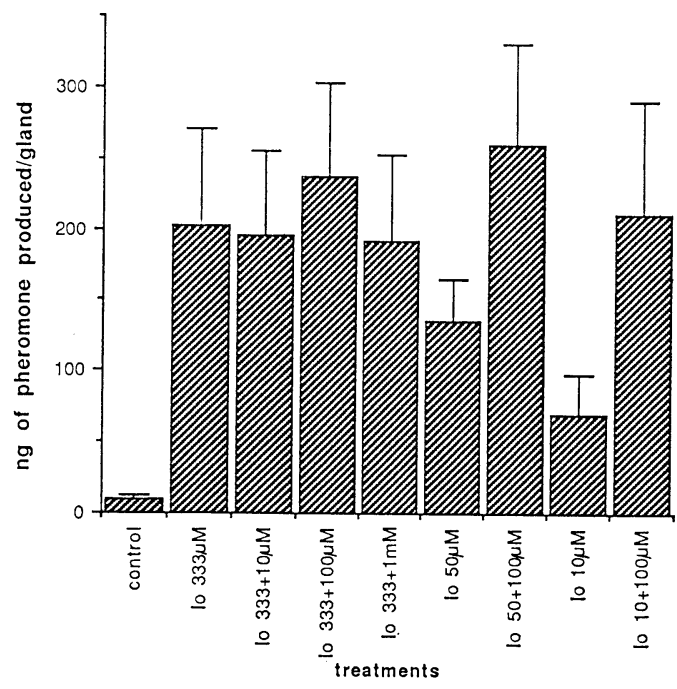

(b) Effect of forskolin in the presence of calcium ionophore

Control: glands in Grace's medium; Io $333 \mu \mathrm{M}$, Io $50 \mu \mathrm{M}$ and Io $10 \mu \mathrm{M}$ : calcium ionophore controls at 333,50 or $10 \mu \mathrm{M}$ concentration; Io $333+$ $10 \mu \mathrm{M}$, Io $333+100 \mu \mathrm{M}$, Io $333+1 \mathrm{~mm}$, Io $50+$ $100 \mu \mathrm{M}$ and Io $10+100 \mu \mathrm{M}$ contain 333,50 or 10 $\mu \mathrm{M}$ calcium ionophore + respective concentrations of forskolin indicated. Otherwise refer to Fig. 2. Results of Io $50+100 \mu \mathrm{M}$ and Io $10+100 \mu \mathrm{M}$ treatments significantly differ from those of controls at $p<0.01$ level in Student's $t$ test.

Fig. 3 In vitro effect of MIX or forskolin in the presence of calcium ionophore on pheromone production in $B$. mori. 
study, forskolin was added in different amounts to the above medium. When $100 \mu \mathrm{M}$ was added only a slight increase $(20 \%)$ in bombykol production was obtained (Fig. 3(b)). The stimulative effect, however, was much more profound when calcium ionophore was employed at lower concentrations. With $50 \mu \mathrm{M}$ ionophore, an addition of $100 \mu \mathrm{M}$ forskolin gave a twofold increase (Fig. 3(b)). A medium containing $100 \mu \mathrm{M}$ forskolin and only $10 \mu \mathrm{M}$ calcium ionophore increased pheromone production more than threefold (Fig. 3(b)).

\section{Effect of Lanthanium Ion in the Presence of Bom-PBAN-I in Vitro}

The inhibitory action of lanthanium ion was studied with different doses of PBAN along with a series of different lanthanium ion concentrations. The most profound, total inhibitory effect was achieved with a relatively low PBAN dose (2 ng/vial); $100 \mu \mathrm{M}$ lanthanium ion resulted in 50\% inhibition (Fig. 4). With higher doses of PBAN (5 ng/vial or $10 \mathrm{ng} /$ vial) a concentration of 1 or $5 \mathrm{~mm}$ lanthanium ion, respectively, was necessary to reach $50 \%$ inhibition in pheromone production; $10 \mathrm{~mm}$

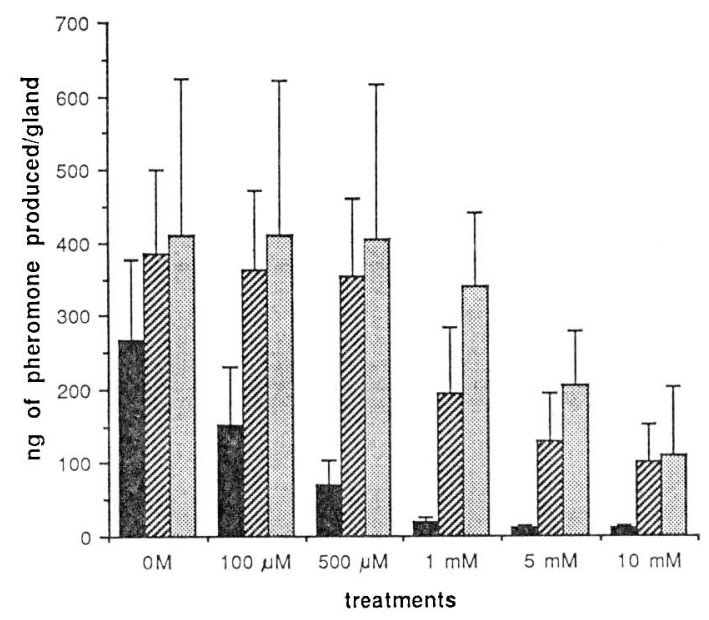

Fig. 4 In vitro inhibitory action of lanthanium ion in the presence of 2, 5, $10 \mathrm{ng} B o m$-PBAN-I on pheromone production in $B$. mori.

Solid columns represent 2 ng PBAN, striped ones $5 \mathrm{ng}$ PBAN, and dotted ones $10 \mathrm{ng}$ PBAN/vial. On horizontal axis respective concentrations of lanthanium ion are indicated. Thin bars represent standard deviation. lanthanium ion induced about $75 \%$ inhibition with both doses (Fig. 4).

\section{DISCUSSION}

A series of in vivo and in vitro experiments was carried out to study the possible involvement of cyclic nucleotides and calcium (or both) in the mode of action of PBAN.

Injection of different cyclic nucleotides into decapitated B. mori females revealed dosedependent action in pheromone production. Cyclic AMP proved to be the strongest stimulant and these observations suggest that cAMP may play a role as a second messenger.

The in vivo cyclic nucleotide tests, however, may serve only as guidelines, since direct action in $B$. mori has not yet been proved. The cAMP may act on the whole body indirectly and in a more complex way, or externally, as a hormone does, as was shown by Devroetes. ${ }^{27)}$ Our in vitro investigations did not confirm the expected cAMP involvement in PBAN action. The negative results obtained with various nucleotides, MIX and forskolin may be due to poor penetration into the target cells, ${ }^{28)}$ insufficient direct stimulation of $B$. mori pheromone glands under our experimental conditions, inadequate informations from the measurement of pheromone production in which the chemicals are involved as second messenger, i.e. the stimulation of cAMP content may have been insufficient to initialize measurable bombykol production or some other unknown factors. It must be noted that in Manduca sexta, the pupal prothoracic glands could not be stimulated by forskolin to produce ecdysone, although it has been proved that prothoracicotropic hormone (PTTH) induces cAMP formation and functions as second messenger for ecdysone production. ${ }^{29)}$ From these results it was concluded that the prothoracic glands apparently have a low level of forskolinstimulatable adenylate cyclase activity and/or a high level of phosphodiesterase activity (resulting in the quick degradation of cAMP if present). On the other hand, in Locusta migratoria, in which cAMP had also been proved to be the second messenger of the antidiuretic hormone, MIX alone did not affect rectal cAMP levels and was ineffective on 
rectal water reabsorption, whereas forskolin was found to induce noticeable response. ${ }^{30)}$

Remarkable potentiations were observed, however, when MIX was added to medium containing PBAN or when MIX or forskolin was applied in the presence of calcium ionophore. These results suggest that without initial stimulation or triggering of pheromone production, no enhancement could be achieved in B. mori. On the other hand, when low pheromone production is initiated (either directly by PBAN or indirectly by calcium ionophore), elevated pheromone production can be measured in the presence of MIX or forskolin.

As far as the stimulation of glands are concerned, there may be differences between species as well. In $H$. armigera, both MIX and forskolin induced a significant increase in cAMP levels in glands and stimulated ${ }^{14} \mathrm{C}$ acetate incorporation into the pheromone glands and the major pheromone component. ${ }^{11)}$ When the glands of S. litura were incubated in vitro with MIX (1 mM) pheromone production increased twofold, while forskolin had no effect (Fónagy, unpublished observations). Regarding the present experiments, the reason still remains unclear as to why forskolin did not exert further effect when incubated with PBAN but affected pheromone production in a positive way when combined with calcium ionophore. A possible interpretation may be that a more precisely coordinated (hormonesecond messenger-enzyme activation) system is switched on following PBAN action and a less specific (or a different one?), during only calcium ionophore incubation. The demonstrated stimulating effect of MIX in both cases, however, provides an overall indication for a possible cAMP involvement in the mode of action of PBAN. Actually, similar enhanced effect was observed in pupal $M$. sexta prothoracic glands under in vitro conditions where PTTH (0.1 Unit) and MIX $(50 \mu \mathrm{M})$ together induced cAMP accumulation, whereas separately these were relatively ineffective. ${ }^{29)}$

Nevertheless, it may be concluded from the present study that different drugs, known to increase intracellular cAMP level, exerted positive/stimulating effect on in vitro pheromone production in the presence of PBAN or calcium ionophore. Further studies are in progress regarding the more precise quantification of the described potentiation effects. Direct measurement (on a time-course basis) of cAMP is required in the same system, since the increased pheromone production observed may be regarded as indirect proof. Moreover, the measurement of cAMP may throw a light on the negative results obtained following only MIX and forskolin treatments.

In the course of study on the mode of action of PBAN and the secondary messenger system involved, we have unequivocal evidence that the hormone requires extracellular calcium and/or calcium influx to initiate de novo pheromone production (Fig. 4). A stimulatory role of calcium ion has been already proved for PBAN action in the pheromone glands of $B$. mori, because calcium ionophore mimicked pheromonotropic effect of PBAN. ${ }^{14)}$ Based on our findings, we suggest that calcium ion has a decisive function instead of a simply permissive role. The positive correlation found between the amount of PBAN and lanthanium ion employed clearly shows relations between PBAN receptor sites and their calcium dependence due to the fact that they can be dose dependently antagonized. Similar dose-dependent antagonizing effect of lanthanium ion has been found in $M$. sexta prothoracic glands incubated with PTTH. ${ }^{31}$

Our experiments have provided some pieces of evidence regarding the sequence of events which take place following PBAN action, like necessary influx of calcium ion, and suggested the involvement of cAMP as second messenger. Further detailed studies are, however, required in this field, since the different physiological mechanisms involved in PBAN action in lepidopterans indicate diversity, ${ }^{14-17)}$ and the mediation of hormonal effect seems to be more complex than it was originally envisioned.

\section{ACKNOWLEDGMENTS}

Dr. Adrien Fónagy is indepted to STA JISTEC for the receipt of a research fellowship. This research was supported by STA (Japan).

\section{REFERENCES}

1) A. K. Raina \& J. A. Klun: Science 225, 531 (1984) 
2) Y. Ohguchi, K. Tatsuki, K. Usui, K. Arai, M. Kurihara, K. Uchiumi \& J. Fukami: Jpn. J. Appl. Entomol. Zool. 29, 265 (1985)

3) A. K. Raina: J. Chem. Ecol. 14, 2063 (1988)

4) T. Ando, R. Arima, M. Uchiyama, H. Nagasawa, T. Inoue \& A. Suzuki: Agric. Biol. Chem. 52, 881 (1988)

5) A. Rafaeli \& V. Soroker: J. Chem. Ecol. 15, 447 (1989)

6) H. Jaffe, A. K. Raina \& D. K. Hayes: "Insect Neurochemistry and Neurobiology," ed. by A. B. Borkovec \& D. B. Gelman, Humana, Clifton, New Jersey, p. 219, 1986

7) A. K. Raina, H. Jaffe, J. A. Klun, R. L. Ridgway \& D. K. Hayes: J. Insect Physiol. 33, 809 (1987)

8) A. K. Raina, H. Jaffe, T. G. Kempe, P. Keim, R. W. Blacher, H. M. Fales, C. T. Riley, J. A. Klun, R. L. Ridgway \& D. K. Hayes: Science 244, 796 (1989)

9) A. Kitamura, H. Nagasawa, H. Kataoka, T. Inoue, S. Matsumoto, T. Ando \& A. Suzuki: Biochem. Biophys. Res. Commun. 163, 520 (1989)

10) A. Kitamura, H. Nagasawa, H. Kataoka, T. Ando \& A. Suzuki: Agric. Biol. Chem. 54, 2495 (1990)

11) A. Rafaeli \& V. Soroker: Mol. Cel. Endocrinol. 65, 43 (1989)

12) V. Soroker \& A. Rafaeli: Insect Biochem. 19, 1 (1989)

13) R. Arima, K. Takahara, T. Kadoshima, F. Numazaki, T. Ando, M. Uchiyama, H. Nagasawa, A. Kitamura \& A. Suzuki: Appl. Entomol. Zool. 26, 137 (1991)

14) A. Fónagy, S. Matsumoto, K. Uchiumi, C. Orikasa \& T. Mitsui: J. Pesticide Sci. 17, 47 (1992)

15) P. E. A. Teal, J. H. Tumlinson \& H. Oberlander: Proc. Natl. Acad. Sci. U.S.A. 86, 2488 (1989)

16) T. A. Christensen, H. Itagaki, P. E. A. Teal, R. D. Jasensky, J. H. Tumlinson \& J. G. Hildebrand: Proc. Natl. Acad. Sci. U.S.A. 88, 4971 (1991)

17) R. A. Jurenka, G. Fabrias \& W. L. Roelofs: Insect Biochem. 21, 81 (1991)

18) A. Rafaeli, V. Soroker, B. Kamensky \& A. K. Raina: J. Insect Physiol. 36, 641 (1990)

19) K. B. Seamon, W. Padgett \& J. W. Daly: Proc. Natl. Acad. Sci. U.S.A. 78, 3363 (1981)

20) W. Montague \& J. R. Cook: Biochem. J. 122, 115 (1971)

21) D. R. Pfeiffer, R. W. Taylor \& H. A. Lardy: Ann. N.Y. Acad. Sci. 307, 402 (1978)

22) W. Y. Cheung: Science 207, 19 (1980)

23) R. P. Bodnaryk: Insect Biochem. 13, 111 (1983)
24) W. A. Smith \& W. L. Combest: "Comprehensive Insect Physiology, Biochemistry and Pharmacology," ed. by G. A. Kerkut \& L. I. Gilbert, Vol. 8, Pergamon Press, Oxford, pp. 263-299, 1985

25) G. B. Weiss: Annu. Rev. Pharmacol. 14, 343 (1974)

26) S. Matsumoto, A. Kitamura, H. Nagasawa, H. Kataoka, C. Orikasa, T. Mitsui \& A. Suzuki: J. Insect Physiol. 36, 427 (1990)

27) P. N. Devroetes: "Advances in Cyclic Nucleotide Research," ed. by P. Greengard \& G. A. Robinson, Raven Press, New York, pp. 55-93, 1983

28) A. L. Lehninger: "Biochemistry," Worth Publishers, New York, 1979

29) W. A. Smith \& L. I. Gilbert: Insect Biochem. 16, 143 (1986)

30) J.-P. E. Harault \& J. P. Proux: J. Insect Physiol. 33, 487 (1987)

31) W.A. Smith, L.I. Gilbert \& W.E. Bollenbacher: Mol. Cell Endocrinol. 39, 71 (1985)

\section{要 約}

\section{カイコにおける性 フェロモンの生産に対する環 状ヌクレオチドの影響}

Adrien FónAGy，松本正吾 内海恭一, 満井 喬

断頭したカイコの雌蛾に cAMP, cGMP, ジブチリル cAMP $(50,250,500 \mu \mathrm{g})$ を注射すると濃度依存的に性 フェロモンであるボンビコールの生産が誘起され，その 中でも， cAMP が最も効果があった。 しかし，これら のヌクレオチドを含む培地 $(1 \mu \mathrm{M} \sim 10 \mathrm{~mm})$ で $\mathrm{PBAN}$ (フェロモン生合成活性化神経ペプチド)の標的器官であ るフェロモン腺を培養してもボンビコールの生産は促さ れなかった。一方, 同じin vitro 条件下で, 環状ヌクレ オチドホスホジェステラーゼの阻害剤である MIX (50 $\mu \mathrm{M})$ は PBAN によるボンビコールの生産を $30 \sim 60 \%$ 高め, MIX (100 $\mu \mathrm{M})$ あるいは, アデニレートシクラー ゼの賦活化剤である forskolin $(100 \mu \mathrm{M})$ はカルシウム イオノフォアによるボンビコールの生産を $2 \sim 3$ 倍増加 させた. さらに, カルシウムイオンの細胞内への流入を 阻止するランタニウムイオン $(100 \mu \mathrm{M} \sim 10 \mathrm{~mm})$ は濃度 依存的に PBAN によるボンビコール生産を抑制した。 これらの結果から, カイコのボンビコール生産にはフェ ロモン腺におけるカルシウムイオンの細胞内一の流入が 重要な役割をなすとともに， CAMP も何らかの役割を 担っていることが示唆された。 